\title{
Peran Learning Goal Orientation dan Big Five Personality terhadap Adaptabilitas Karier Siswa SMK
}

\author{
Jati Fatmawiyati, Duta Nurdibyanandaru, Dewi Retno Suminar \\ Fakultas Psikologi, Universitas Airlangga, Jl. Airlangga 4-6, Surabaya, Indonesia \\ e-mail: jati.fatmawiyati-2017@psikologi.unair.ac.id
}

\begin{abstract}
The purpose of this study is to investigate learning goal orientation (LGO) and Big Five Personality in effect with carrier adaptability. This study used quantitative approach. Simple random sampling technique was used to recruit 93 twelve-grades SMKN " $X^{\prime \prime}$ Malang students majoring in Teknik Komputer dan Jaringan (TKJ) and Rekayasa Perangkat Lunak (RPL). We used adapted instruments consist of LGO Scale, Big Five Inventory (BFI) and Career AdaptAbilities Scale (CAAS). The simultaneously regression test shows that both LGO and Big Five Personality has an effect to carrier adaptability (37\%). LGO partially has effect on carrier adaptability. For all big five personality dimensions, opennes to experience has effect to carrier adaptability but other dimensions such as extraversion, conscientiousness, neuroticism, and agreeableness has no effect.
\end{abstract}

Keywords: learning goal orientation, big five personality, career adaptability, vocational school student

\begin{abstract}
Abstrak
Penelitian ini bertujuan untuk mengetahui pengaruh learning goal orientation (LGO) dan big five personality terhadap adaptabilitas karier. Penelitian memakai pendekatan kuantitatif. Teknik simple random sampling dipilih untuk menetapkan sampel penelitian sejumlah 93 siswa kelas XII SMKN "X" Malang jurusan Teknik Komputer dan Jaringan (TKJ) dan Rekayasa Perangkat Lunak (RPL). Penelitiaan memakai LGO Scale, Big Five Inventory (BFI) dan Career AdaptAbilities Scale (CAAS) sebagai alat ukur. Uji regresi secara simultan membuktikan terdapat pengaruh LGO dan big five personality terhadap adaptabilitas karier (37\%). Secara parsial, uji regresi memperlihatkan baik LGO maupun dimensi opennes to experience pada big five personality memengaruhi adaptabilitas karier. Sedangkan dimensi extraversion, conscientiousness, neuroticism dan agreeableness pada big five personality tidak memengaruhi adaptabilitas karier.
\end{abstract}

Kata Kunci: learning goal orientation, big five personality, adaptabilitas karier, siswa SMK

\section{Pendahuluan}

Sekolah Menengah Kejuruan (SMK) adalah pendidikan formal jenjang menengah yang melaksanakan pendidikan kejuruan. Merujuk pada Peraturan Pemerintah Nomor 29 Tahun 1990, tujuan pendidikan SMK yaitu terutama membuat siswa siap memasuki lapangan kerja dan mengembangkan sikap profesional mereka. Pendidikan kejuruan juga mengutamakan agar siswa mampu mengembangkan kemampuannya untuk melakukan jenis pekerjaan tertentu. Dengan demikian, tamatan pendidikan kejuruan sepatutnya mampu melakukan pekerjaan sesuai minat dan bakat yang didukung keterampilannya secara profesional (Kemendikbud, 2017).

Undang-undang mengenai sistem pendidikan nasional nomor 20 tahun 2003 (Departemen Pendidikan Nasional, 2003) juga menegaskan bahwa pendidikan kejuruan menyiapkan siswa utamanya untuk bekerja di bidang tertentu. Pendidikan jenjang menengah mempunyai tujuan khusus menyiapkan peserta didik untuk mampu bekerja menempati lowongan pekerjaan yang tersedia sesuai kompetensi program keahlian. Dengan demikian pendidikan kejuruan bermaksud menyiapkan siswa agar mampu bekerja 
atau berkarier pada bidang tertentu sesuai dengan kompetensinya. Sementara itu, tuntutan dari perusahaan pun membutuhkan pekerja dengan kompetensi dan keahlian yang relevan dengan spesifikasi bidang pekerjaan (Wiroko, 2017).

Kenyataan di lapangan menunjukkan kesenjangan antara kondisi ideal dengan realita. Terdapat lulusan SMK yang memiliki pekerjaan tidak relevan dengan keahliannya. Permasalahan ini terjadi di SMKN "X" Malang. Sekolah ini merupakan Sekolah Menengah Kejuruan Negeri yang terletak di kota Malang, Jawa Timur. Sekolah ini mempunyai 9 jurusan yaitu Multimedia, Animasi, Mekatronika, Produksi Grafika, Persiapan Grafika, Teknik Komputer dan Jaringan (TKJ), Rekayasa Perangkat lunak (RPL), Logistik dan Perhotelan. Siswa sekolah ini berjumlah sekitar 3300 siswa, yang mana setiap angkatan kelas berisi kurang lebih 1100 siswa (SMKN “X” Malang, 2020). Latar belakang sosial ekonomi siswa SMKN "X" Malang mayoritas berada pada tingkat menengah ke bawah. Hal ini terlihat dari orang tua siswa yang mayoritas berpendidikan tingkat menengah, bekerja sebagai karyawan swasta maupun berwiraswasta dengan penghasilan rata-rata berkisar upah minimum regional kota Malang (SMKN “X” Malang, 2018a).

Tidak semua tamatan SMKN " $X$ " Malang bekerja relevan dengan keahlian atau kompetensi yang dikuasai. Kondisi demikian ditunjukkan dari laporan Penyerapan Tamatan SMKN "X" Malang jurusan Rekayasa Perangkat Lunak (RPL) serta Teknik Komputer dan Jaringan (TKJ). Jurusan RPL adalah program keahlian yang mencetak tenaga terampil di bidang pemrograman software. Sedangkan jurusan TKJ adalah program keahlian yang menyiapkan peserta didik di bidang perangkat keras komputer dan jaringan sebagai tenaga profesional (SMKN "X" Malang, 2020).

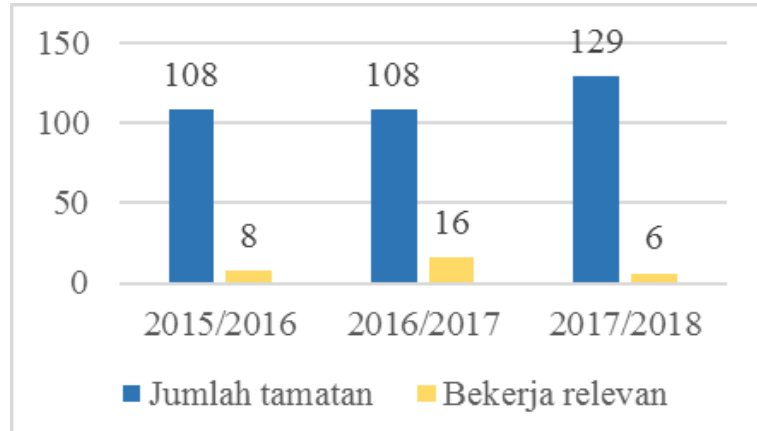

Gambar 1. Grafik tamatan jurusan RPL SMKN "X" Malang

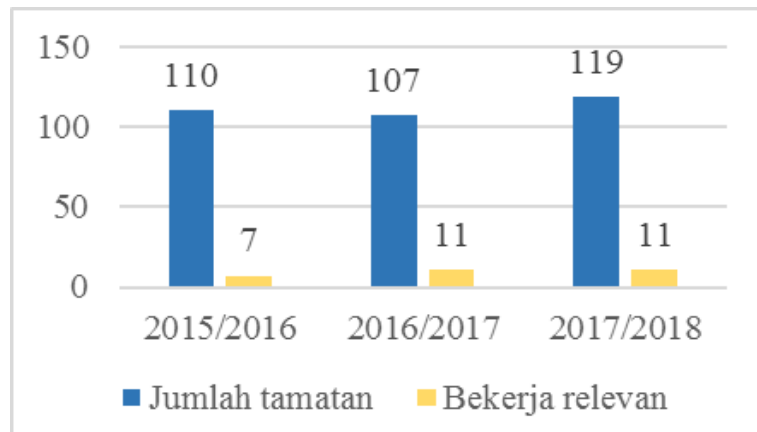

Gambar 2. Grafik tamatan jurusan TKJ SMKN "X" Malang

Berturut-turut sepanjang tiga tahun (tahun ajaran 2015/2016, 2016/2017 dan 2017/2018) diketahui hanya sedikit jumlah tamatan jurusan RPL dan TKJ yang bekerja relevan dengan bidang keahlian selama masa transisi karier (SMKN " $X$ " Malang, 2019). Data mengenai tamatan jurusan RPL dan TKJ SMKN "X" Malang tersebut tertera pada gambar 1 serta gambar 2.

Data tamatan jurusan RPL SMKN " $X$ " Malang yang tertera pada gambar 1 menunjukkan bahwa pada tahun ajaran 2015/2016 hanya $8(7 \%)$ siswa dari total 108 siswa tamatan RPL yang berkarier relevan dengan keahlian yang dikuasai. Pada tahun ajaran 2016/2017 tercatat 16 (15\%) siswa saja tamatan RPL yang bekerja relevan dengan jurusan. Terakhir, pada tahun ajaran 2017/2018 terdata hanya $6(15 \%)$ siswa tamatan RPL yang bekerja sesuai dengan bidang keahliannya (SMKN "X" Malang, 2019).

Data tamatan jurusan TKJ SMKN " $X$ " Malang yang tertera pada gambar 2 menunjukkan bahwa pada tahun ajaran 
2015/2016 terdapat sekitar $7(6 \%)$ siswa dari total 110 tamatan TKJ yang memiliki pekerjaan relevan dengan keahliannya. Siswa yang telah bekerja sesuai dengan jurusan pada tahun ajaran 2016/2017 hanya $11(10 \%)$ orang dari total 107 siswa jurusan TKJ yang lulus. Tahun ajaran 2017/2018 tercatat hanya 11 (9\%) siswa dari total 119 siswa tamatan TKJ yang bekerja relevan dengan bidang keahlian. Dengan demikian dapat disimpulkan bahwa hanya sedikit jumlah tamatan siswa jurusan RPL dan TKJ yang bekerja relevan dengan bidang keahlian (SMKN “X” Malang, 2019).

Penelitian yang dilakukan van Vianen dkk. (2012) dan Tolentino dkk., (2014) memperlihatkan bahwa seseorang yang mampu melakukan adaptasi dalam kariernya akan mendukung lulusan baru memperoleh pekerjaan yang relevan bahkan dalam kondisi ekonomi yang serba tidak pasti. Seseorang yang mampu melakukan adaptasi dalam kariernya juga diprediksi akan berhasil menjalani masa transisi karier. Ia pun lebih mampu menemukan kesempatan kerja serta memutuskan pilihan karier yang lebih berkualitas dan baik. Selain itu, kemampuan beradaptasi karier yang tinggi mengarahkan individu melakukan strategi pencarian kerja tipe eksplorasi dan terfokus, yang berorientasi untuk memperoleh pekerjaan sesuai kualifikasi, minat dan kebutuhan individu (Koen dkk., 2010).

Rendahnya tingkat adaptabilitas karier mengarahkan individu untuk menggunakan strategi pencarian kerja serampangan (Koen dkk., 2010). Strategi pencarian kerja serampangan antara lain pencarian kerja yang dilakukan oleh individu dengan standar kerja yang rendah dan tidak jelas, mencari pekerjaan apa pun tanpa memperhatikan jenis pekerjaan (Koen dkk., 2010). Dengan kata lain, individu yang memiliki kemampuan beradaptasi karier yang rendah akan menerima pekerjaan apapun, bahkan jenis pekerjaannya yang tidak sesuai dengan bidang keahlian yang dimiliki. Oleh karena itu, berkaitan dengan sedikitnya jumlah lulusan SMK Negeri "X" Malang jurusan RPL dan TKJ yang bekerja relevan dengan bidang keahlian, maka hal ini diduga menjadi indikasi kurangnya kemampuan beradaptasi karier pada siswa. Siswa diprediksi kurang memiliki kesiapan untuk menjalani masa transisi karier dari sekolah ke dunia kerja.

Kesiapan peserta didik SMKN " $X$ " Malang saat berada pada lingkungan kerja bisa diketahui juga dari hasil Survei Kepuasan Pelanggan terhadap pelayanan yang diberikan oleh sekolah. Hasil survei pada tahun 2016 dan 2018 (SMKN "X" Malang, 2018b) menunjukkan bahwa unsur kesiapan kerja siswa menduduki penilaian kepuasan yang paling rendah. Selain itu, kesiapan mental dan etos kerja siswa paling banyak dikritik oleh perusahaan. Berdasarkan hasil survei tersebut dapat diindikasikan bahwa kesiapan kerja siswa SMKN "X" Malang tergolong rendah dari sudut pandang perusahaan sebagai stakeholder.

Memperhatikan fenomena yang terjadi berturut-turut sepanjang tiga tahun di SMKN "X" Malang, memperlihatkan keadaan yang mungkin pula dapat terjadi pada siswa yang duduk di kelas XII jurusan RPL dan TKJ SMKN "X" Malang. Siswa kelas XII merupakan siswa tingkat akhir yang akan menjadi tamatan baru serta menjalani masa transisi. Selaras dengan hal tersebut, Babarović dan Šverko (2016) menjelaskan bahwa siswa di kelas akhir sekolah menengah berfokus pada transisi karier yang akan datang. Koen dkk. (2010) juga menjelaskan bahwa lulusan atau tamatan baru merupakan individu yang akan menjalani transisi dari sekolah ke dunia kerja (school to work transition). Hal yang mungkin dapat dilakukan agar lebih berhasil dalam menjalani masa transisi karier, salah satunya yaitu dengan cara mempersiapkan karier individu secara tepat (Koen dkk., 2010). 
Kesiapan individu guna menghadapi hambatan atau rintangan saat transisi karier yaitu adaptabilitas karier (Savickas \& Porfeli, 2012) atau diistilahkan dengan career adaptability. Savickas dan Porfeli (2012) mendefiniskan adaptabilitas karier sebagai konstruk psikososial yang menunjukkan sumberdaya individu untuk menangani transisi kerja, tugas-tugas perkembangan karier serta trauma pribadi yang berkenaan dengan peran karier atau pekerjaan.

Keterlibatan individu dalam perilaku adaptif sebelum transisi karier akan mendukung persiapan yang menumbuhkan kualitas pekerjaan dan kesuksesan karier para pencari kerja (Koen dkk., 2010; Hirschi, 2010). Individu akan memahami kompetensi yang dimiliki, memeriksa pemilihan karier dan melakukan perencanaan karier yang memungkinkannya memperoleh pekerjaan sesuai dengan diri individu (Koen dkk., 2010). Dengan demikian, agar siswa yang akan lulus sukses menghadapi masa transisi karier serta mampu menemukan pekerjaan yang sesuai bidang keahliannya, maka mereka perlu mengembangkan adaptabilitas kariernya.

Adaptabilitas karier terdiri dari empat dimensi (Savickas, 1997). Dimensi ini antara lain perhatian (corcern), pengendalian (control), rasa ingin tahu (curiousity) dan keyakinan (confidence). Dimensi-dimensi ini merepresentasikan sumberdaya sekaligus strategi adaptabilitas karier yang dipakai untuk mengorganisasikan tugas perkembangan karier, transisi karier dan pengalaman trauma yang berkenaan dengan karier individu (Gunawan, 2014). Sumber daya adaptasi karier merupakan kekuatan atau kapasitas pengaturan diri yang dapat dilakukan individu untuk menyelesaikan masalah yang tidak diketahui, tidak jelas dan bersifat kompleks yang disebabkan adanya tugas kejuruan atau pekerjaan, transisi kerja serta trauma kerja individu (Savickas \& Porfeli, 2012).
Dimensi perhatian (corcern), artinya individu mempunyai perhatian terhadap karier dan mempersiapkan masa depan kariernya. Wujud dari perhatian individu terhadap karier berupa pandangan optimis dan perencanaan yang tepat untuk menghadapi berbagai hal yang akan terjadi di masa depan. Keduanya, baik rasa optimisme maupun perencanaan karier tidak lepas dari pertimbangan pengalaman masa lalu dan kondisi yang individu hadapi saat ini (Savickas \& Porfeli, 2012).

Dimensi pengendalian (control), artinya individu yakin akan memiliki masa depannya sendiri serta bertanggung jawab terhadap kariernya (Savickas \& Porfeli, 2012). Menurut Savickas dan Porfeli (2012) pengendalian (control) mendukung seseorang lebih memiliki rasa tanggung jawab menata baik diri maupun lingkungannya untuk menghadapi berbagai perubahan melalui ketekunan, usaha dan kedisiplinan diri. Wujud control ini meliputi sikap tegas dan asertif yang membuat individu mau terlibat pada tugastugas perkembangan karier, bukan malah menangguhkannya apalagi melalaikannya. Sikap ini akan mendukung individu untuk turut serta menjalani aktivitas-aktivitas yang dapat menambah ketegasannya dalam membuat keputusan karier.

Dimensi rasa ingin tahu (curiosity), merujuk pada sikap mengeksplorasi beragam peran dan situasi terkait karier yang dibutuhkan individu di masa mendatang (Savickas \& Porfeli, 2012). Wujud dari rasa ingin tahu berupa inisiatif untuk menelaah beragam jenis pekerjaan yang ingin ditekuni dan berupaya meraih kesempatan untuk bekerja pada bidang yang dikehendaki. Curiousty ini akan menumbuhkan sikap penyesuaian dalam diri individu seperti berani mencoba, tidak takut mengambil risiko dan berinisiatif mengajukan berbagai pertanyaan seputar karier (Savickas \& Porfeli, 2012).

Terakhir, dimensi keyakinan diri (confidence), yaitu tingkat keyakinan individu untuk mampu mengatasi masalah 
dan melakukan upaya yang diperlukan dalam menyelesaikan hambatan (Savickas \& Porfeli, 2012). Wujud keyakinan diri berupa sikap yang terus-menerus berjuang, tekun dan tidak mudah menyerah. (Savickas \& Porfeli, 2012).

Penerapan adaptabilitas karier siswa kelas XII SMKN " $X$ " jurusan TKJ dan RPL masih tergolong kurang. Hal ini diketahui dari hasil wawancara dengan 9 siswa kelas XII jurusan TKJ dan RPL. Hasil wawancara menunjukkan bahwa siswa belum sepenuhnya merefleksikan karakteristik-karakteristik yang tertuang dalam dimensi adaptabilitas karier.

Berdasarkan hasil wawancara yang dilakukan pada 17 September 2018, diketahui bahwa siswa kelas XII SMKN " $X$ " Malang jurusan TKJ belum berpikir secara matang dan jelas mengenai rencana kariernya ke depan setelah menyelesaikan sekolah. Ada kecenderungan siswa menyerahkan tanggung jawab kariernya kepada pihak Bursa Kerja Khusus (BKK) sekolah. Temuan ini dapat dimaknai siswa cenderung memiliki kepedulian karier yang rendah. Sebagaimana konsep career concern (Savickas, 1997), individu dengan kepedulian karier rendah akan menyerahkan tanggung jawab atau tugastugas terkait karier kepada orang lain, misalnya konselor karier atau orang tua. Sebaliknya individu yang peduli dengan karier akan mempunyai keyakinan dan sikap optimis yang tampak dari perencanaan kariernya (Savickas, 1997). Senada dengan pernyataan Hermawati (2013) individu yang bersikap optimis dalam orientasi masa depan, ia akan membuat sejumlah antisipasi untuk masa mendatang sehingga memiliki orientasi yang jelas pada pilihan pekerjaan serta perencanaan karier yang matang.

Berdasarkan hasil wawancara beberapa siswa jurusan RPL (17 September 2018) diketahui mengalami kebingungan apakah akan terjun ke dunia kerja atau meneruskan pendidikannya di perguruan tinggi. Temuan ini mengindikasikan bahwa siswa tidak mempunyai ketetapan pada kariernya. Siswa menunjukkan adanya kebingungan karier yang ditampakkan dari belum mampunya siswa memutuskan pilihan kariernya ke depan. Menurut Savickas (1997) individu yang mengalami kebingungan karier (career indecision) mengindikasikan bahwa individu tersebut memiliki pengendalian karier (career control) yang rendah. Sebaliknya, individu yang memiliki pengendalian karier tinggi, memiliki ketegasan dalam mengambil keputusan terkair karier.

Berdasar hasil wawancara (17 September 2018) juga dapat diketahui bahwa siswa kelas XII SMKN "X" Malang jurusan RPL dan TKJ masih tergolong kurang dalam memiliki rasa keingintahuan terhadap karier mereka ke depannya. Siswa belum menunjukkan upaya pencarian informasi yang memadai terkait pekerjaan atau karier yang ingin ditekuni. Hal ini bertentangan dengan konsep career curiousity yang mengarah kepada ketekunan dan rasa ingin tahu untuk mempelajari lebih jauh tentang tipe pekerjaan serta peluang yang ada pada pekerjaan (Gunawan, 2014; Savickas, 1997).

Siswa kelas XII SMKN "X" Malang jurusan RPL juga belum menerapkan konsep dari career confidence. Diantaranya yakni siswa cenderung mudah menyerah dan kurang tekun dalam menyelesaikan tugas-tugas dalam praktek kerja industri, yang pada dasarnya merupakan bagian dari tugas kariernya. Hal ini berlawanan dengan konsep confidence yang mengindikasikan adanya keyakinan dan upaya individu untuk mengatasi masalah dan hambatan karier yang dihadapi (Savickas \& Porfeli, 2012).

Learning goal orientation (LGO) menjadi salah satu faktor yang berpengaruh terhadap tingkat adaptabilitas karier individu (Tolentino dkk., 2014). Dweck (1986) mendefiniskan LGO sebagai karakteristik yang relatif atau cenderung stabil, yang berupa usaha untuk 
mengembangkan kompetensi serta ketekunan pada diri individu untuk menghadapi hambatan.

Individu dengan LGO tinggi menganggap kemampuan sebagai suatu hal yang fleksibel, bukan sebagai sesuatu yang tetap atau tidak dapat diubah (Dweck, 1986). Ketika individu memahami kemampuan sebagai suatu hal yang bersifat fleksibel, maka penguasaan kemampuan bergantung pada usaha yang dilakukan. Berpegang pada orientasi tersebut, individu cenderung terlibat dalam perilaku adaptif untuk meningkatkan kompetensinya. Terkait dengan karier, maka individu akan terdorong untuk meningkatkan kompetensi dalam karier, yakni kemampuan beradaptasi dalam kariernya.

Individu yang memiliki LGO menilai kondisi yang menantang sebagai peluang untuk pengembangan dirinya (Tolentino dkk., 2014). Dengan demikian, individu yang memiliki LGO lebih tinggi dimungkinkan memahami dan menilai kondisi kehidupannya yang menantang, dalam hal ini yaitu masa transisi karier sebagai faktor pendukung karier daripada mempersepsikannya sebagai hambatan. Hal ini diprediksi dapat memaksimalkan pertumbuhan pribadi pada diri individu serta mendukung individu untuk lebih mengembangkan kemampuannya dalam beradaptasi dengan tantangan karier (Tolentino dkk., 2014). Dengan kata lain, pola motivasi adaptif yang melekat pada LGO memfasilitasi pembentukan pengaturan diri untuk beradaptasi karier karena pola motivasi adaptif ini mendukung pembentukan dan pemeliharaan karier serta pencapaian tujuan individu (Tolentino dkk., 2014).

Individu yang memiliki LGO tinggi memandang kegagalan dan kinerja yang buruk mencerminkan kemampuan mereka. Oleh karena itu, kegagalan dipandang sebagai umpan balik yang berguna yang memberikan peluang belajar. Individu dengan LGO yang tinggi meningkatkan usahanya setelah mengalami kegagalan karena individu menganggap bahwa usaha merupakan sarana menuju pencapaian tujuan mereka (Dweck \& Leggett, 1988). Dengan demikian, LGO dikaitkan dengan reaksi adaptif terhadap tugas-tugas kompleks, mengerahkan upaya, bertahan dalam menghadapi kegagalan, menggunakan strategi yang efektif, belajar dari kegagalan, menghasilkan peningkatan kinerja dan pencapaian tujuan (Noordzij dkk., 2013).

Individu yang memiliki LGO tinggi diketahui memiliki regulasi atau pengaturan diri yang efektif dalam bidang akademik serta pekerjaan (Payne dkk., 2007; Elliot dkk., 1999 dalam Faadhilah, 2016). Individu yang memiliki tingkat LGO tinggi berdasarkan sejumlah penelitian terdahulu menunjukkan peningkatan dalam pembelajaran mandiri, aspirasi karier dan kepuasan karier (Tolentino dkk., 2014). Dalam setting pekerjaan, LGO sangat relevan dalam lingkungan kerja saat ini, yang mengharuskan pekerja untuk proaktif, menyelesaikan masalah, bersikap inovatif dan proaktif terhadap gagasan-gagasan baru, dan beradaptasi dengan situasi yang baru dan terus berubah (Luthans, 2011).

Penelitian tentang LGO dengan adaptabilitas karier dilakukan oleh Tolentino dkk. (2014) pada mahasiswa di Australia. Penelitian ini membuktikan bahwa ada korelasi positif antara LGO dengan adaptabilitas karier. Korelasi paling kuat terjadi antara LGO dengan dimensi confidence dan curiousity. Penelitian lain terkait LGO dilakukan oleh Faadhilah (2016) pada 83 mahasiswa tingkat akhir Universitas Airlangga. Penelitian ini memperlihatkan hasil adanya korelasi positif antara LGO dengan adaptabilitas karier. Berbeda dengan penelitian oleh Tolentino dkk. (2014), penelitian Faadhilah (2016) membuktikan korelasi paling kuat terjadi antara LGO dengan dua dimensi adaptabilitas karier yaitu control dan concern. 
Faktor kepribadian juga berasosiasi dengan dimensi adaptabilitas karier (Savickas \& Porfeli, 2012). Lebih spesifik, van Vianen dkk. (2012) menyatakan bahwa dimensi kepribadian big five berasosiasi dengan adaptabilitas karier. Kepribadian big-five adalah pendekatan dalam Psikologi yang dipergunakan untuk mengetahui dan mengukur kepribadian dengan memandang kepribadian berdasarkan lima tipe yaitu ekstraversion, agreeableness, openness to experience, conscientiousness serta neurotism.

Pada dimensi extraversion, individu ekstrovert suka menjadi pusat aktivitas sosial, suka menjalin relasi dengan orang lain dan memupuk interaksi positif. Dalam masa transisi karier, individu extrovert mungkin sangat terampil dalam mencari dan memanfaatkan dukungan dari orang lain, sehingga mampu mendukung diri mereka dengan sumber daya sosial yang diperlukan saat menghadapi ketidakpastian dan stres yang terkait dengan transisi karier (van Vianen dkk., 2012).

Dimensi agreeablenes mengacu pada perilaku interpersonal, mempercayai orang lain, peduli, baik hati dan lembut (McCrae \& Costa, 1992; dalam van Vianen dkk., 2012). Individu ini termasuk pribadi yang mampu bersepakat, percaya kepada orang lain dan bersikap kooperatif (Costa \& Mc Crae, 1992 dalam Cervone \& Pervin, 2012). Agreeableness berkorelasi dengan adaptabilitas karier diperkirakan karena agreeableness berperan sebagai kemampuan sosial yang sangat penting untuk mendukung eksplorasi karier (Li dkk., 2015).

Dimensi conscientiousness mengacu pada pengendalian diri, kebutuhan untuk pencapaian, ketekunan, bekerja keras, bertanggung jawab, dan terorganisir (Judge dkk., 1999, dalam van Vianen dkk., 2012). Oleh karenanya conscientiousness mendorong perilaku mencari pekerjaan yang efektif (van Vianen dkk., 2012), berhubungan positif dengan perencanaan karier (Rogers dkk., 2008), serta memiliki kepercayaan diri yang lebih tinggi (Pulford \& Sohal, 2006; Schaeferet, dkk., 2004) dalam van Vianen dkk. (2012). Penelitian oleh Chong dan Leong (2017) juga menunjukkan bahwa conscientiousness memiliki pengaruh terhadap tingkat adaptabilitas karier.

Dimensi neuroticism ditandai oleh ketidakstabilan, ketidakamanan pribadi dan depresi, sehingga stabilitas emosinya rendah. Individu dengan neuroticism yang tinggi cenderung menunjukkan kurangnya penyesuaian psikologis positif (Judge dkk., 1999, dalam van Vianen dkk., 2012). Neuroticism dipahami sebagai kebalikan dari kontrol dan individu dengan neurotisme tinggi menilai peristiwa stres sebagai ancaman daripada tantangan. Oleh karena itu, neuroticism berhubungan negatif dengan dengan dimensi kontrol dan kepercayaan diri pada adaptabilitas karier (van Vianen dkk., 2012).

Dimensi openness to experience mengacu pada imajinasi, keingintahuan intelektual, dan fleksibilitas berpikir (McCrae \& Costa, 1992, dalam van Vianen dkk., 2012). Pribadi yang memiliki minat pada sesuatu yang baru dan inovatif diprediksi akan cenderung bersikap imajinatif, intelek dan sensitif (Costa \& Mc Crae 1992 dalam Cervone \& Pervin, 2012). Oleh karenanya openness to experience terkait dengan rasa ingin tahu, lebih terlibat dalam perencanaan masa depan dan karier (Rogers dkk., 2008) sehingga openness to experience terkait secara positif terhadap kemampuan adaptabilitas karier (van Vianen dkk., 2012).

Sejumlah penelitian (Li dkk., 2015; Teixeira dkk., 2012; Zacher, 2014; Rossier dkk., 2012; van Vianen dkk., 2012) telah dilakukan untuk menganalisis kepribadian big five dengan adaptabilitas karier. Beberapa penelitian tersebut menunjukkan hasil yang beragam. Sebagai contoh, penelitian Zacher (2014) pada 1.723 karyawan di Australia menemukan bahwa dimensi conscientiousness, openness to 
experience, agreeableness dan extraversion berkorelasi positif, sedangkan neuroticism ditemukan berkorelasi negatif dengan adaptabilitas karier. Berbeda dengan penelitian Li dkk., (2015) pada 264 mahasiswa di China, membuktikan ada korelasi positif antara conscientiousness, openness to experience dan agreeableness dengan adaptabilitas karier, neuroticism ditemukan berkorelasi negatif, tetapi extraversion tidak berkorelasi dengan adaptabilitas karier. Oleh karena hasil penelitian yang beragam, maka penelitian mengenai penelitian big five personality dengan adaptabilitas karier perlu dibuktikan kembali secara empiris.

Selain itu, sejauh pengamatan peneliti, penelitian serupa tentang big five personality dengan adaptabilitas karier, baru sebatas menggunakan sampel penelitian dari kalangan mahasiswa, lulusan perguruan tinggi dan pekerja yang dilakukan di luar Indonesia. Untuk penelitian sebelumnya yang terkait LGO dengan adaptabilitas karier (Faadhilah, 2016; Tolentino dkk., 2014), penelitian dilakukan sebatas pada mahasiswa sebagai sampel penelitian. Sedangkan dalam penelitian ini, akan dilakukan penelitian dalam konteks yang berbeda, yakni konteks siswa SMK yang akan menjalani masa transisi karier dari bangku sekolah ke dunia kerja.

Kondisi negara, budaya, ekologi dan ekonomi yang tidak sama berpotensi memunculkan peluang serta desakan atau tuntutan yang berlainan dalam menumbuhkembangkan kemampuan beradaptasi individu (Savickas \& Porfeli, 2012). Perbedaan individu dalam kemampuannya beradaptasi dan faktor penyebab yang saling berkaitan menjadi hal penting untuk dipelajari. Pendekatan tradisional terkait pilihan karier tidak lagi relevan karena kondisi dan lingkungan kerja yang berubah dengan cepat, sehingga individu pun dituntut mempersiapkan diri serta mengantisipasi perubahan ini. Oleh karena itu, penting dilakukan penelitian yang menelaah sumber daya, sikap, disposisi, dan perilaku yang mendukung individu untuk beradaptasi dalam karier (Savickas \& Porfeli, 2012).

Adanya fakta tentang jumlah lulusan SMK yang relatif sedikit bekerja relevan dengan keahlian selama masa transisi karier, hasil survei kepuasan pelanggan yang menunjukkan kurangnya kesiapan kerja siswa serta adanya indikasi kurangnya kemampuan adaptabilitas karier siswa kelas XII SMKN "X" Malang jurusan RPL dan TKJ merupakan permasalahan yang perlu untuk diteliti. Mengacu pada latar belakang tersebut, peneliti hendak mengkaji pengaruh LGO dan big five personality terhadap adaptabilitas karier siswa SMKN " $\mathrm{X}$ " Malang jurusan RPL dan TKJ.

\section{Metode Penelitian}

Penelitian ini memakai metode kuantitatif. Apabila ditinjau dari tujuannya, termasuk penelitian korelasional dengan tipe kausal. LGO dan big five personality merupakan variabel independen, sedangkan adaptabilitas karier sebagai variabel dependen dalam penelitian.

Populasi penelitian yaitu siswa yang duduk di kelas XII SMKN "X" Malang jurusan RPL dan TKJ tahun pelajaran 2018/2019 dengan jumlah 263 siswa. Teknik probability sampling dengan metode simple random sampling digunakan untuk menentukan sampel penelitian. Roscoe (Sugiyono, 2011) menyatakan penelitian dengan analisis multivariate (regresi ganda) dapat menentukan jumlah ukuran sampel yakni paling sedikit $10 \mathrm{kali}$ dari jumlah variabel penelitian. Sehingga, jumlah sampel yang digunakan dalam penelitian paling sedikit 10 kali dari 3 variabel yaitu 30 orang. Sampel penelitian jurusan RPL sebanyak 45 orang dari total 135 siswa, sedangkan jurusan TKJ sebanyak 48 orang dari total 128 siswa. Dengan demikian total sampel pada penelitian ini yaitu 93 orang. 
Sebagai alat pengumpul data dipergunakan teknik survei dengan memakai kuesioner. Kuesioner dalam penelitian ini terdiri dari tiga skala.

Pertama, pengukuran big five personality memakai skala Big Five Inventory (BFI). BFI disusun oleh John dan Srivastava (1999). Ramdhani (2012) telah mengadaptasi BFI ini dalam budaya serta bahasa Indonesia. Pada BFI dilakukan Confirmatory Factor Analysis (CFA) untuk menguji kesesuaian masing-masing dimensi dengan nilai $\lambda$ berkisar $\geq .40$ untuk model pengukuran itemnya (Lau dkk., 2010 dalam Ramdhani, 2012). CFA pada BFI ini menghasilkan model yang terdiri dari 28 item dengan kualitas baik dengan skor $\lambda$ antara .43 sampai dengan .80 (Ramdhani, 2012). Adapun reliabilitas Cronbach's Alpha sekitar .60-.79, artinya dapat diterima reliabilitasnya (Sugiyono, 2011). Hasil uji reliabilitas BFI ini memiliki nilai .86, sehingga reliabilitas diterima.

Ramdhani (2012) menunjukkan BFI terbagi atas lima dimensi yaitu extraversion, contoh itemnya "Saya adalah seorang yang bersemangat". Dimensi agreeableness, contoh itemnya "Saya adalah seorang yang suka menjalin kerjasama dengan orang lain". Dimensi conscientiousness, contoh itemnya "Saya adalah seorang yang melakukan pekerjaan hingga tuntas". Dimensi neuroticism, contohnya "Saya adalah seorang yang sering merasa khawatir". Terakhir, dimensi openness to experience, contoh itemnya "Saya adalah seorang yang berdaya cipta".

Kedua, instrumen untuk mengukur LGO yaitu skala Learning Goal Orientation (LGO) Scale. Skala ini disusun Button dkk. (1996) dan diadaptasi dalam bahasa Indonesia oleh peneliti. LGO Scale terdiri dari 8 item dan memiliki internal konsistensi sebesar 87 (Button dkk., 1996). Button dkk. (1996) menetapkan indikator LGO antara lain: memiliki kehendak untuk mengembangkan diri, merepresentasikan kehendak individu untuk ikut serta berbagai aktivitas yang menantang serta mengarah pada tindakan yang memakai unjuk kerja sebelumnya sebagai tolok ukur untuk mengevaluasi unjuk kerja saat ini. Contoh item LGO Scale yakni "Kesempatan untuk mengembangkan kemampuan saya merupakan suatu hal yang penting". Contoh item lainnya, yakni "Saya berusaha keras untuk meningkatkan performa kerja sebelumnya". Penelitian ini memakai batasan $\geq .30$ untuk menentukan bahwa item valid (Azwar, 2016). Hasil uji validitas seluruh item LGO Scale menunjukkan corrected item-total correlation berkisar .41 sampai dengan .52, artinya terbukti valid. Nilai reliabilitas pada LGO Scale ini sebesar .774, sehingga instrumen layak digunakan untuk penelitian.

Ketiga, Career Adapt-Ability Scale $(C A A S)$. CAAS yang disusun Savickas dan Porfeli (2012) dan diadaptasi dalam bahasa Indonesia oleh peneliti dipakai untuk mengetahui tingkat adaptabilitas karier. Hasil uji validitas CAAS menghasilkan corrected item-total correlation sebesar .33 sampai dengan .70, artinya seluruh item (24 butir) dinyatakan valid. Skala CAAS ini memiliki nilai reliabilitas yang baik yakni .924, sehingga layak digunakan untuk penelitian. Skala CAAS terdiri dari 24 item yang terbagi atas empat dimensi. Pertama, dimensi perhatian (career concern), contoh itemnya "Saya mempersiapkan masa depan saya". Dimensi pengendalian (career control), dengan contoh item "Saya membuat keputusan sendiri". Dimensi keingintahuan (career curiosity), contoh itemnya "Saya mencari tahu berbagai pilihan sebelum mengambil keputusan". Terakhir, dimensi keyakinan (career confidence), dengan contoh item "Saya mengatasi hambatan".

Tahap analisa data meliputi uji asumsi klasik yang dilanjutkan dengan uji hipotesis penelitian. Tahap uji asumsi klasik dilakukan untuk memenuhi syarat dilakukannya uji regresi linier berganda. 


\section{Hasil Penelitian dan Pembahasan}

Uji normalitas yang tertera pada tabel 1 menunjukkan tingkat signifikasi pada variabel big five personality sebesar .354; variabel LGO sebesar 479 dan variabel adaptabilitas karier senilai .941. Hasil uji ketiga variabel menunjukkan tingkat signifikansi memiliki nilai lebih dari .05 , artinya keseluruhan variabel berdistribusi normal.

Model regresi yang tepat sepatutnya antara variabel bebas dengan variabel terikat ada korelasi linier (Sugiyono, 2011). Pada tabel 2, variabel big five personality dengan adaptabilitas karier memiliki nilai signifikansi linierity .000. Variabel LGO dengan adaptabilitas karier juga menunjukkan signifikansi linierity .000. Hasil uji linieritas keduanya menunjukkan kurang dari .05, artinya secara signifikan ada hubungan yang linier.

Tidak ditemukannya autokorelasi merupakan bentuk regresi yang tepat (Ghozali, 2011). Pada tabel 3, tertera ketiga variabel penelitian menunjukkan nilai asymp.sig sebesar .603, yang lebih tinggi dari .05. Hal ini berarti tidak ditemukan gejala autokorelasi.

Tabel 1

Uji Normalitas

\begin{tabular}{lc}
\hline \multicolumn{1}{c}{ Variabel } & Asymp.Sig (2-tailed) \\
\hline Big Five Personality & .354 \\
LGO & .479 \\
\hline
\end{tabular}

Tabel 2

Uji Linieritas

\begin{tabular}{lc}
\hline \multicolumn{1}{c}{ Variabel } & Asymp.Sig (2-tailed) \\
\hline Adaptabilitas Karier & \\
Big Five Personality & .603 \\
LGO & \\
\hline
\end{tabular}

Tabel 3

Uji Autokorelasi

\begin{tabular}{lcc}
\hline \multicolumn{1}{c}{ Variabel } & & Linierity Sig. \\
\hline Adaptabilitas Karier $*$ Big & .000 \\
Five & & \\
Adaptabilitas Karier *LGO & .000 \\
\hline
\end{tabular}

Tabel 4

\begin{tabular}{lcc}
\multicolumn{3}{c}{ Uji Multikolinieritas } \\
\multicolumn{1}{c}{ Variabel } & \multicolumn{2}{c}{ Collinierity Statistic } \\
& VIF & Tolerance \\
\hline Big Five Personality & 1.338 & .748 \\
LGO & 1.338 & .748 \\
\hline
\end{tabular}

Tabel 5

Uji Heteroskedastisitas

\begin{tabular}{lc}
\hline \multicolumn{1}{c}{ Variabel } & Signifikansi \\
\hline Big Five Personality & .661 \\
LGO & .932 \\
\hline
\end{tabular}

Tidak ditemukannya multi-kolinieritas pada penelitian merupakan bentuk regresi yang sesuai dengan ketentuan (Ghozali, 2011). Pada tabel 4 tertera hasil perhitungan variabel LGO dan big five personality bernilai VIF hitung lebih kecil dibandingkan dengan VIF banding $(1.338<$ 10.00) dan tolerance hitung lebih besar dari tolerance banding $(.748>.10)$. Mengacu pada hasil uji multikolineritas ini, maka diketahui tidak ada multikolinieritas pada data penelitian.

Tidak ditemukannya gejala heteroskedositas menjadi ketentuan dilakukannya regresi (Ghozali, 2011). Hasil uji heteroskedasitas variabel penelitian tertera pada tabel 5. Hasil uji heteroskedasitas big five personality siginifikansinya adalah .661 sedangkan LGO berada pada angka .932. Siginifikansi pada kedua variabel bernilai lebih dari .05, hal ini membuktikan tidak ditemukannya gejala heteroskedasitas.

Berdasarkan keseluruhan hasil uji asumsi klasik membuktikan data pada penelitian telah memenuhi syarat untuk dianalisis dengan uji regresi linier berganda. Pertama, hasil analisis data mengenai pengaruh secara bersama-sama variabel big LGO dan five personlity terhadap variabel adaptabilitas karier dapat diketahui di tabel 6. Analisis regresi secara bersama-sama atau simultan (Uji F) tertera nilai $\mathrm{F}=26.618$ yang memiliki signifikansi $.000<.05$. Uji regresi berganda ini membuktikan ada pengaruh yang signifikan antara variabel LGO dan big five 
personality terhadap variabel adaptabilitas karier secara simultan. Hal ini dapat dimaknai bahwa LGO dan big five personality yang ada pada diri siswa kelas XII SMKN "X" Malang jurusan RPL dan TKJ memberikan pengaruh terhadap kemampuan adaptabilitas karier mereka. Jika tingkat LGO dan big five personality siswa semakin tinggi, maka tingkat adaptabilitas karier pada diri siswa pun semakin tinggi. Sebaliknya, jika tingkat LGO dan big five personality siswa semakin rendah, maka tingkat adaptabilitas karier pada siswa juga semakin rendah.

Berdasarkan hasil penelitian ini dapat dijelaskan bahwa saat siswa mampu meningkatkan sumber dayanya melalui LGO dan big five personality, maka hal ini akan mendukung siswa untuk dapat lebih peduli dan menyiapkan masa depan kariernya (career concern). Siswa juga lebih mampu untuk bertanggung jawab dan mengontrol hal-hal yang berkaitan dengan kariernya (career control). Siswa akan lebih baik dalam menggali beragam peran dan situasi terkait karier yang diperlukannya pada masa mendatang (career curiousity). Selain itu, peningkatan sumber daya siswa melalui LGO dan big five personality juga meningkatkan keyakinan dan upaya untuk dapat menuntaskan kesulitan maupun masalah karier yang dihadapinya (career confidence).

Tabel 7 yaitu hasil uji determinasi menunjukkan nilai koefisien $R=.610$, hal ini mengindikasikan ada korelasi kuat antara $L G O$ dan big five personality terhadap variabel adaptabilitas karier. Seberapa kuat pengaruh LGO dan big five personality terhadap adaptabilitas karier siswa pun dapat diketahui dari nilai Rsquare $=.372$. Hal ini mengindikasikan besarnya persentase sumbangan pengaruh LGO dan big five personality terhadap adaptabilitas karier yaitu sebesar $37 \%$, pengaruh $63 \%$ lainnya dijelaskan variabel lain yang tidak termasuk dalam penelitian ini.
Tabel 6

Uji Analisis Regresi Bersama-sama (Uji F)

\begin{tabular}{llccr}
\hline \multicolumn{5}{c}{ ANOVA $^{\mathbf{b}}$} \\
\hline \multicolumn{5}{c}{ Mean } \\
Model & df & Square & F & Sig. \\
\hline Regression & 2 & 4357.73 & 26.618 & $.000 \mathrm{a}$ \\
Residual & 90 & 163.717 & & \\
Total & 92 & & & \\
\hline
\end{tabular}

a. Predictors: (Constant), LGO, Big Five

b. Dependent Variable: Adaptabilitas Karier

Tabel 7

Uji Determinasi

\begin{tabular}{lccc}
\hline \multicolumn{3}{c}{ Summary } \\
\hline $\mathrm{R}$ & $\mathrm{R}$ & $\begin{array}{c}\text { Adjusted } \\
\text { Square }\end{array}$ & $\begin{array}{c}\text { Std. Error } \\
\text { of the } \\
\text { Estimate }\end{array}$ \\
\hline $.610^{\mathrm{a}}$ & .372 & .358 & 12.795 \\
\hline $\begin{array}{l}\text { a. Predictors: (Constant), LGO, Kepribadian } \\
\text { Big Five }\end{array}$
\end{tabular}

Table 8

Uji Koefisien Regresi Parsial (Uji t)

\begin{tabular}{|c|c|c|c|c|c|}
\hline \multirow{3}{*}{ Model } & \multicolumn{3}{|c|}{ Coefficients $^{\mathrm{a}}$} & \multirow[b]{3}{*}{$\mathrm{T}$} & \multirow[b]{3}{*}{ Sig } \\
\hline & \multicolumn{2}{|c|}{$\begin{array}{l}\text { Unstandardized } \\
\text { Coefficients }\end{array}$} & \multirow{2}{*}{$\begin{array}{c}\text { Std } \\
\text { Coeff } \\
\text { Beta }\end{array}$} & & \\
\hline & B & $\begin{array}{l}\text { Std. } \\
\text { Error }\end{array}$ & & & \\
\hline (Constant) & -13.960 & 19.125 & & -.730 & 467 \\
\hline$L G O$ & .972 & .301 & .339 & 3.224 & 002 \\
\hline \multicolumn{6}{|l|}{ Big Five: } \\
\hline Extraversion & 676 & .537 & .140 & 1.259 & 211 \\
\hline Agreeableness & .104 & .760 & .014 & .137 & 891 \\
\hline $\begin{array}{l}\text { Conscientious- } \\
\text { ness }\end{array}$ & .439 & .511 & .103 & .861 & 392 \\
\hline Neuroticism & .412 & 1.253 & .033 & .329 & 743 \\
\hline Opennes & 1.256 & .551 & .227 & 2.280 & 025 \\
\hline
\end{tabular}

Faktor yang mungkin dapat memengaruhi adaptabilitas karier selain LGO dan big five personality salah satunya yaitu faktor dukungan sosial (Hirschi, 2009; Wang \& Fu, 2015; Giffari, 2017). Berbeda dengan LGO dan big five personality yang merupakan faktor internal memengaruhi adaptabilitas karier, dukungan sosial menjadi faktor eksternal yang berpengaruh terhadap adaptabilitas karier (Sulistiani \& Handoyo, 2018). Faktor dukungan sosial bisa bersumber dari orang tua, guru, teman, keluarga, significant other dan lingkungan sekolah atau institusi pendidikan (Hirschi, 2009; Han \& Rojewski, 2015; Tian \& Fan, 2014). Penelitian membuktikan dukungan sosial 
yang tinggi menjadi prediksi kuat dalam memengaruhi tingkat adaptabilitas karier seseorang (Han \& Rojewski, 2015; Tian \& Fan, 2014).

Menurut Hirschi (2010) dukungan sosial mampu memengaruhi adaptabilitas karier karena dukungan sosial yang berbentuk dukungan instrumental dan emosional dari beragam pihak akan membantu seseorang dalam menyusun rencana karier dan menjelajahi seputar kariernya. Dukungan sosial ini dapat berupa informational support, positive social interaction, tangible support, dan emotional support yang bersumber dari guru, lingkungan sekolah atau institusi pendidikan, keluarga, teman atau significant other (Yousefi dkk., 2011). Pelayanan bimbingan karier, ketersediaan informasi karier, seminar pengembangan karier, tes minat bakat tentang karier, job shadowing dan konseling karier yang diberikan secara profesional oleh pihak sekolah juga merupakan dukungan sosial yang memengaruhi tingkat adaptabilitas karier (Han \& Rojewski, 2015). Dengan demikian, penelitian selanjutnya dapat melihat faktor eksternal yang memengaruhi adaptabilitas karier, salah satunya yakni dukungan sosial yang bersumber dari lingkungan sekolah atau institusi pendidikan, guru, keluarga, teman atau significant other.

Hasil penelitian kedua, pada tabel 8 Uji Regresi Parsial (Uji t) dapat dilihat analisis data mengenai pengaruh satu variabel bebas secara parsial koefisien regresi (variabel LGO dan big five personality) terhadap variabel adaptabilitas karier. Perhitungan tersebut menunjukkan hasil sebagai berikut: 1) Pengaruh LGO terhadap adaptabilitas karier diperoleh $\mathrm{t}$ hitung $=3.224>\mathrm{t}$ table $=1.665$, taraf signifikansi $.002<.05$, artinya secara parsial LGO memberikan pengaruh yang signifikan terhadap adaptabilitas karier; 2) Pengaruh big five personality dimensi extraversion terhadap adaptabilitas karier diperoleh $\mathrm{t}$ hitung sebesar $=1.259<\mathrm{t}$ tabel $=$
1.665, dengan signifikansi .211> .05, sehingga terbukti secara parsial dimensi extraversion pada big five personality tidak memberikan pengaruh pada adaptabilitas karier; 3) Pengaruh big five personality dimensi agreeableness terhadap adaptabilitas karier diperoleh thitung $=.137$ $<\mathrm{t}$ table $=1.665$, dengan signifikansi .891 $>.05$, artinya secara parsial dimensi agreeableness pada big five personality tidak memengaruhi adaptabilitas karier; 4) Pengaruh big five personality dimensi conscientiousness terhadap adaptabilitas karier, diperoleh t hitung $=.861<\mathrm{t}$ table $=$ 1.665 , taraf signifikansi $.392>.05$, artinya terbukti secara parsial dimensi conscientiousness pada big five personality tidak memengaruhi adaptabilitas karier; 5) Pengaruh big five personality dimensi neuroticism terhadap adaptabilitas karier, diperoleh $\mathrm{t}$ hitung $=.329<\mathrm{t}$ table $=1.665$, taraf signifikansi $.743>.05$, artinya secara parsial dimensi neuroticism pada big five personality tidak memiliki pengaruh pada adaptabilitas karier; 6) Pengaruh big five personality dimensi opennes to experience terhadap adaptabilitas karier, diperoleh $\mathrm{t}$ hitung $=2.280>\mathrm{t}$ table $=1.665$, taraf signifikansi $.025<.05$, bermakna secara parsial dimensi opennes to experience pada big five personality memiliki pengaruh yang signifikan pada adaptabilitas karier.

Persamaan regresi untuk variabel LGO dan big five personality terhadap variabel adaptabilitas karier adalah sebagai berikut: $\mathrm{Y}=-13.960+.972 \mathrm{LGO}+.104$ agreeableness +.439 conscientiousness +.676 extraversion +.412neuroticism+1.256opennes to experience.

Persamaan regresi di atas memiliki makna bahwa variabel LGO memiliki nilai koefisien regresi sebesar .972, dapat dimaknai apabila ada kenaikan pada LGO senilai satu satuan dan variabel lainnya dianggap tetap, maka akan menyebabkan berubahnya nilai adaptabilitas karier dengan peningkatan sebesar .972 . Sedangkan apabila variabel big five personality yang meliputi dimensi 
agreeableness,

neuroticism,

conscientiousness, extraversion dan opennes to experience serta variabel LGO nilainya adalah konstan, maka nilai adaptabilitas karier adalah -13.960, yang mana nilai tersebut menunjukkan tingkat adaptabilitas karier yang rendah.

$$
\text { Pengujian regresi parsial }
$$

memperlihatkan variabel LGO secara signifikan memberikan pengaruh pada variabel adaptabilitas karier. Dimensi LGO berpengaruh secara positif terhadap adaptabilitas karier, mengandung makna apabila tingkat LGO siswa semakin kuat maka tingkat adaptabilitas karier siswa juga akan semakin kuat. Berlaku kebalikannya, tingkat LGO siswa yang semakin lemah akan membuat tingkat adaptabilitas karier siswa semakin lemah pula. Temuan penelitian selaras dengan penelitian Tolentino dkk. (2014) dengan responden mahasiswa dua perguruan tinggi Australia dan Faadhilah (2016) dengan partisipan sejumlah mahasiswa tingkat akhir Universitas Airlangga. Individu harus memiliki concern, control, curiousity dan confidence untuk memiliki kemampuan beradaptasi dalam karier. Berkaitan dengan kompetensi curiousity (eksplorasi) dan confidence (keyakinan memecahkan masalah) keduanya perlu LGO yang tinggi (Savickas, 2005). Hal ini karena LGO dikaitkan dengan reaksi adaptif terhadap tugas-tugas kompleks, mengerahkan upaya, bertahan dalam menghadapi kegagalan, menggunakan strategi efektif, belajar dari kegagalan, menghasilkan peningkatan kinerja dan pencapaian tujuan (Noordzij dkk., 2013).

Individu dengan LGO tinggi memiliki suatu keyakinan bahwa kemampuan yang dimiliki dapat ditempa dan dikembangkan secara berkelanjutan. Merujuk pada teori incrimental, individu yang memiliki LGO tinggi menyakini bahwa kemampuan yang dimiliki individu dapat diasah dan ditingkatkan melalui tantangan, sehingga kemampuan individu dapat berkembang. Individu yang memiliki LGO tinggi akan cenderung senang dengan tugas-tugas yang memungkinkan adanya pengembangan kemampuan dan keahlian (Dweck \& Leggett, 1988). Mengacu pada hal tersebut, terdapat kecenderungan pada diri individu untuk terlibat dalam perilaku adaptif guna meningkatkan atau mengembangkan kompetensinya. Apabila karakterstik ini dikaitkan dengan dimensi karier, maka individu akan terdorong untuk meningkatkan kompetensi yang terkait dengan kariernya, yakni kompetensi atau kemampuan beradaptasi dalam kariernya.

Selain itu, individu yang memiliki LGO tinggi memiliki pola respon adaptif yang baik, antara lain bersifat gigih atau pantang menyerah, memiliki upaya yang kuat dalam mengatasi hambatan serta cenderung menyukai tantangan (Yi \& Hwang, 2003). Dengan demikian, pola motivasi adaptif yang melekat dalam LGO yang dimiliki siswa kelas XII SMKN "X" Malang jurusan RPL dan TKJ akan memfasilitasi pembentukan pengaturan diri yang diperlukan untuk dapat beradaptasi karier. Hal ini karena pola motivasi adaptif tersebut akan mendukung terbentuk dan terpeliharanya karier pada diri siswa serta pencapaian tujuan karier pada diri siswa (Tolentino dkk., 2014).

Kondisi yang sulit atau menantang tidak dilihat sebagai suatu hambatan oleh individu dengan LGO tinggi, tetapi dinilai sebagai kesempatan atau peluang yang memberikan ruang pada mereka untuk dapat berkembang. Oleh karena itu, individu yang memiliki LGO lebih tinggi dimungkinkan memahami dan menilai kondisi kehidupan yang dihadapinya, dalam hal ini yaitu masa transisi karier dari dunia pendidikan ke dunia kerja sebagai faktor yang mendukung kariernya, daripada menilai sebagai sebuah hambatan. Dengan demikian, siswa kelas XII SMKN "X" Malang jurusan RPL dan TKJ yang memiliki LGO tinggi akan memahami dan menilai kondisi yang dihadapinya, yaitu masa transisi karier dari dunia pendidikan SMK ke dunia kerja sebagai tantangan 
yang dihadapi untuk mendukung pengembangan kariernya, bukan menilai masa transisi karier sebagai hambatan. Hal ini dapat memaksimalkan perkembangan pribadi siswa untuk mengembangkan kemampuannya dalam beradaptasi dengan tantangan karier (Tolentino dkk., 2014). Adapun tantangan karier yang dihadapi siswa kelas XII SMKN "X" Malang, dalam hal ini salah satunya adalah mampu memperoleh pekerjaan yang relevan atau sesuai dengan bidang keahlian yang dimilikinya selama masa transisi karier.

Hasil uji regresi secara parsial memperlihatkan pada variabel big five personality hanya dimensi openess to experience yang berpengaruh terhadap adaptabilitas karier. Openess to experience memberikan pengaruh positif terhadap adaptabilitas karier, artinya apabila tingkat openess to experience siswa semakin tinggi maka tingkat adaptabilitas karier pada diri siswa juga akan semakin tinggi. Hal ini berlaku sebaliknya, jika tingkat openess to experience siswa semakin rendah, maka tingkat adaptabilitas karier siswa pun semakin rendah. Hasil ini digambarkan melalui persamaan regresi $\mathrm{Y}=-13.960+$ 1.256 opennes to experience. Nilai koefisien regresi untuk variabel big five personality dimensi opennes to experience adalah 1.256, dapat dimaknai apabila dimensi opennes to experience mengalami kenaikan sejumlah satu satuan sedangkan variabel lainnya dianggap tetap, maka akan menyebabkan berubahnya nilai adaptabilitas karier dengan peningkatan sebesar 1.256.

Hasil penelitian mengenai pengaruh positif openness to experience dengan adaptabilitas karier ini serupa dengan sejumlah penelitian terdahulu. Sejumlah penelitian tersebut diantaranya oleh Teixeira dkk. (2012) pada 908 responden terdiri dari mahasiswa, lulusan perguruan tinggi dan karyawan di Brasil; Zacher (2014) dengan responden 1.723 karyawan di Australia; van Vianen dkk. (2012) dengan responden 465 mahasiswa di
Belanda; dan penelitian yang dilakukan oleh Nilforooshan dan Salimi (2016) kepada 201 mahasiswa di Iran.

Penjelasan mengenai mekanisme pengaruh dimensi openness to experience terhadap adaptabilitas karier berkaitan dengan karakteristik openness to experience. Karakteristik yang dimaksud yaitu memiliki imajinasi, keingintahuan intelektual, dan fleksibilitas, sehingga hal ini terkait dengan rasa ingin tahu individu. Individu yang terbuka lebih ingin tahu tentang diri mereka sendiri dan lebih suka berbagai pilihan yang berkaitan dengan ide, nilai, dan pengalaman. Rasa ingin tahu ini memungkinkan mendukung individu untuk melakukan eksplorasi terhadap kariernya (Li dkk., 2015; McCrae \& Costa, 1992; Le Pine dkk., 2000, dalam van Vianen dkk., 2012).

Adanya rasa ingin tahu tersebut mengindikasikan keterkaitan antara openness to experience dengan curiousity pada subskala adaptabilitas karier. Sebagaimana penjelasan Savickas dan Porfeli (2012), career curiousity merujuk pada sikap mengeksplorasi beragam peran dan situasi terkait karier yang diperlukan oleh individu di masa mendatang. Adanya curiousity ini akan mendukung seseorang menggali hal-hal yang berkenaan dengan penyesuaian diri dalam lingkungan atau konteks kerja. Individu juga terbantu untuk membayangkan dirinya berada pada beragam situasi maupun peran yang terkait dengan karier (Savickas \& Porfeli, 2012). Dengan demikian, siswa SMKN " $X$ " Malang jurusan RPL dan TKJ yang memiliki openess to experience tinggi memungkinkan mereka mempunyai curiousity yang kuat dalam mengeksplorasi karier sehingga dapat meningkatkan adaptabilitas kariernya.

Openness to experience yang tinggi pada diri seseorang akan mendorong individu untuk lebih terlibat dalam perencanaan masa depan (Prenda \& Lachman, 2001, dalam van Vianen dkk., 2012) dan perencanaan karier (Rogers dkk., 
2008) daripada mereka yang kurang terbuka untuk pengalaman baru. Openness to experience dapat memotivasi individu untuk siap menghadapi masa depan, sehingga individu terdorong membuat perencanaan karier sebagai kesiapannya menghadapi masa depan kariernya. Adanya perencanaan karier ini mengindikasikan hubungan antara openness to experience dan concern pada subskala adaptabilitas karier. Dengan demikian, siswa kelas XII SMKN "X" Malang jurusan RPL dan TKJ yang memiliki openess to experience tinggi memungkinkan mendukung siswa untuk peduli terhadap masa depan karier yang diwujudkan dengan melakukan perencanaan karier sehingga dapat meningkatkan adaptabilitas kariernya.

Openness to experience berhubungan dengan keingintahuan intelektual, fleksibilitas kognitif serta fungsi intelektual yang lebih canggih (McCrae \& John, 1992, dalam Teixeira dkk., 2012). Sebagai konsekuensinya, individu intelektual mungkin merasa dirinya lebih kompeten untuk menyelesaikan masalah dan mengatasi situasi yang menuntut, sehingga menampilkan tingkat confidence dan control yang lebih tinggi (Teixeira dkk., 2012). Dimensi confidence ini mengarah pada tingkat keyakinan individu untuk mampu mengatasi masalah dan melakukan upaya dalam menyelesaikan hambatan (Savickas \& Porfeli, 2012). Dengan demikian, siswa kelas XII SMKN " $X$ " Malang jurusan RPL dan TKJ yang memiliki openness to experience yang tinggi mendukung keyakinan siswa agar mampu memecahkan masalah dan melakukan upaya-upaya untuk menuntaskan hambatan karier.

Uji regresi secara parsial membuktikan bahwa dimensi extraversion pada variabel big five personality secara signifikan tidak berpengaruh terhadap adaptabilitas karier. Hasil ini selaras dengan penelitian pada 264 mahasiswa di China oleh Li dkk. (2015). Extraversion tidak memiliki pengaruh terhadap adaptabilitas karier disebabkan extraversion mungkin sebagian besar lebih memberikan dampak terhadap perilaku interpersonal daripada memengaruhi perilaku karier. Individu extravert menyukai pusat aktivitas sosial dan menumbuhkan interaksi positif (van Vianen dkk., 2012). Oleh karena itu, berdasarkan karakter individu extrovert yang demikian maka menjadikan siswa yang memiliki extraversion tinggi, karakteristiknya tidak memengaruhi adaptabilitas karier yang dimiliki siswa.

Karakteristik individu ekstrovert yang lebih fokus tertuju kepada hal lainnya daripada diri mereka sendiri sehingga eksplorasi yang di-upgrade bukanlah dirinya, melainkan hal lainnya. Hal ini menjadikan karakteristik extraversion yang tinggi pada siswa tidak mendukung perilaku eksplorasi kariernya (Nauta, 2007). Dengan kata lain, siswa dengan extraversion yang tinggi akan mencari tahu hal-hal diluar dirinya yang cenderung tidak berkaitan dengan karier. Oleh karena itu, perilaku eksplorasinya tidak mendukung individu untuk mengetahui beragam peran serta situasi yang penting untuk kariernya di masa mendatang. Mengacu pada pengujian data, secara signifikan dimensi agreeableness tidak memberikan pengaruh pada adaptabilitas karier. Hasilnya serupa dengan temuan van Vianen dkk. (2012) yang meneliti mahasiswa di Belanda dan Rossier dkk. (2012) dengan partisipan mahasiswa, job seekers, pekerja, dan pensiunan di Swiss.

Penjelasan mengenai mekanisme tidak adanya pengaruh dimensi agreeableness terhadap adaptabilitas karier berkaitan dengan karakteristik agreeablenes yang mengacu pada perilaku interpersonal, saling percaya mempercayai orang lain, peduli, baik hati dan lembut (McCrae \& Costa, 1992; dalam van Vianen dkk., 2012). Karakteristik agreeableness yang demikian menjadikan individu sebagian besar lebih memberikan dampak terhadap perilaku interpersonal daripada memengaruhi perilaku karier (van Vianen 
dkk., 2012). Agreeableness berkaitan dengan kecenderungan interpersonal seperti pada extraversion. Individu agreeableness cenderung lebih altruistik, simpatik, dan percaya pada orang lain, sehingga tampaknya tidak ada dasar teoretis atau empiris untuk mengaitkan antara agreeableness dengan adaptabilitas karier (Reed dkk., 2004). Dengan demikian, karakteristik agreeableness yang melekat pada diri siswa kelas XII SMKN "X" Malang jurusan RPL dan TKJ lebih berdampak kepada perilaku interpersonal daripada memengaruhi karier siswa, sehingga karakteristik ini pun tidak memengaruhi adaptabilitas karier siswa.

Hasil pengujian data memperlihatkan bahwa dimensi conscientiousness pada big five personality secara signifikan tidak memberikan pengaruh terhadap adaptabilitas karier. Hal ini berkaitan dengan aspek dependability yang terkandung dalam conscientiousness tidak ditemukan memprediksi kinerja adaptif atau tidak mendukung kemampuan beradaptasi individu (Griffin \& Hesketh, 2005; Pulakos dkk., 2002).

Aspek dependability terdiri dari faset: (a) order, merupakan kecenderungan untuk teratur dan rapi; (b) dutifulness, kepatuhan yang ketat pada seperangkat standar; dan (c) deliberation, menggambarkan seseorang yang berhati-hati, bijaksana dan terencana. Ketika situasi membutuhkan kemampuan beradaptasi, ketiga aspek dependability tersebut kemungkinan tidak dapat berfungsi dengan baik untuk dapat beradaptasi. Hal ini disebabkan aspek dependability lebih mengarahkan individu untuk bertindak serta berpikir dengan konvensional, tidak fleksibel, kaku dan terikat pada aturan yang mungkin mempersulit individu berfungsi dalam lingkungan kerja yang berubah dengan cepat, sehingga tidak mendukung kemampuan beradaptasi individu (Pulakos dkk., 2002). Dependability kemungkinan menjadi indikasi kinerja yang lebih stabil dan konsisten daripada perilaku yang bervariasi dan fleksibel yang diyakini mendasari kinerja adaptif (Pulakos dkk., 2002).

Terkait dengan penelitian ini dapat dinyatakan bahwa dimensi conscientiousness secara signifikan tidak memberikan pengaruh terhadap adaptabilitas karier siswa kelas XII SMKN "X" Malang jurusan RPL dan TKJ diperkirakan karena secara umum siswa lebih terarah untuk berperilaku dan berpikir dengan pola konvensional, kaku dan terikat kuat dengan aturan sehingga conscientiousness pada siswa tidak berpengaruh terhadap kemampuan adaptabilitas karier siswa. Pengujian data secara parsial menghasilkan temuan variabel big five personality dimensi neuroticism tidak memberikan pengaruh pada adaptabilitas karier. Temuan ini berbeda dengan sejumlah penelitian terdahulu yang membuktikan neuroticism berkorelasi negatif terhadap adaptabilitas karier (Rossier dkk., 2012; Li dkk., 2015; Teixeira dkk., 2012; Zacher, 2014; van Vianen dkk., 2012;).

Penjelasan mengenai mekanisme tidak adanya pengaruh dimensi neuroticism terhadap adaptabilitas karier berkaitan dengan karakteristik neuroticism yang ditandai oleh ketidakstabilan, ketidakamanan pribadi dan depresi, sehingga stabilitas emosi yang dimiliki rendah dan cenderung menunjukkan kurangnya penyesuaian psikologis yang positif (Judge dkk., 1999, dalam van Vianen dkk., 2012). Terlebih lagi, karena individu neurotik memiliki kecenderungan untuk pesimisme dan merenungkan pikiran negatif, sehingga individu mungkin kurang peduli tentang masa depan kejuruannya, kurang siap untuk hari esok, dan menjadi kurang mau belajar tentang diri dan pengalaman baru (Nilforooshan \& Salimi, 2016). Dengan demikian, berdasarkan uraian tersebut, menjadikan neuroticism pada diri siswa kelas XII SMKN "X" Malang jurusan RPL dan TKJ tidak berpengaruh terhadap adaptabilitas karier individu. 


\section{Simpulan}

Temuan pada penelitian ini yaitu LGO dan big five personality memberikan pengaruh terhadap kemampuan adaptabilitas karier siswa kelas XII SMKN "X" Malang jurusan RPL dan TKJ. Apabila tingkat LGO dan big five personality semakin tinggi, maka tingkat adaptabilitas karier siswa juga akan semakin tinggi. Hal ini dapat dimaknai bahwa saat siswa mampu meningkatkan sumber dayanya melalui LGO dan big five personality, maka hal ini akan membantu siswa untuk peduli dan menyiapkan masa depan kariernya dengan lebih baik. Siswa juga lebih mampu untuk bertanggung jawab dan mengontrol kariernya ke depan. Tingkat eksplorasi karier mereka pun diprediksi akan lebih baik. Selain itu, peningkatan sumber daya siswa melalui LGO dan big five personality juga membuat mereka lebih yakin dan berupaya kuat untuk dapat menuntaskan hambatan maupun masalah karier yang dihadapi. Sebaliknya, apabila tingkat LGO dan big five personality bernilai rendah, maka tingkat adaptabilitas karier siswa pun akan semakin rendah. Oleh karena itu, bagi siswa penting untuk terlibat kegiatan-kegiatan yang mengembangkan karakteristik LGO dan big five personality, sehingga pola adaptif yang melekat pada kedua faktor ini mampu meningkatkan adaptabilitas karier mereka.

\section{Daftar Pustaka}

Azwar, S. (2016). Penyusunan skala psikologi. Pustaka Pelajar.

Babarović, T., \& Š verko, I. (2016). Vocational development in adolescence: career construction, career decision-making difficulties and career adaptability of Croatian High School students. Primenjena Psihologija, 9(4), 429-447. https://doi.org/10.19090/pp.2016.4.429 $-448$

Button, S. B., Mathieu, J. E., \& Zajac, D.
M. (1996). Goal orientation in organizational research: A conceptual and empirical foundation. Organizational Behavior and Human Decision Processes, 67(1), 26-48. https://doi.org/10.1006/obhd.1996.006 3

Cervone, D., \& Pervin, L. A. (2012). Kepribadian: Teori dan Penelitian (10th ed.). Salemba Humanika.

Chong, S., \& Leong, F. T. L. (2017). Antecedents of career adaptability in strategic career management. Journal of Career Assessment, 25(2), 268-280. https://doi.org/10.1177/106907271562 1522

Departemen Pendidikan Nasional. (2003). Undang-Undang Republik Indonesia Nomor 20 Tahun 2003 tentang Sistem Pendidikan Nasional (pp. 147-173).

Dweck, C. S. (1986). Motivational processes affecting learning. American Psychologist, 41(10), 1040-1048. https://doi.org/10.1037/0003066X.41.10.1040

Dweck, C. S., \& Leggett, E. L. (1988). A social-cognitive approach to motivation and personality. Psychological Review, 95(2), 256-273. https://doi.org/10.1037/0033295X.95.2.256

Faadhilah, A. M. (2016). Hubungan learning goal orientation dengan adaptabilitas (career adaptability) pada mahasiswa tingkat akhir jurusan sastra Jepang universitas Airlangga (Skripsi tidak diterbitkan). Universitas Airlangga, Fakultas Psikologi.

Ghozali, I. (2011). Aplikasi analisis multivariate dengan program SPSS. Badan Penerbit Universitas Diponegoro.

Giffari, N. (2017). Pengaruh social support terhadap career adaptability pada mahasiswa tingkat akhir fakultas Psikologi universitas Airlangga (Skripsi tidak diterbitkan) Universitas Airlangga, Fakultas Psikologi.

Griffin, B., \& Hesketh, B. (2005). Are 
conscientious workers adaptable? Australian Journal of Management, 30(2), 245-259. https://doi.org/10.1177/031289620503 000204

Gunawan, W. (2014). Adaptabilitas karier: Strategi menghadapi afta dan memanfaatkan bonus demografi. Journal Noetic Psychology, 4(2), 110 126.

Han, H., \& Rojewski, J. W. (2015). Gender-specific models of work-bound Korean adolescents' social supports and career adaptability on subsequent job satisfaction. Journal of Career Development, 42(2), 149-164. https://doi.org/10.1177/089484531454 5786

Hermawati, N. (2013). Gambaran orientasi masa depan area pekerjaan pada mahasiswa fakultas psikologi UIN SGD Bandung. Psympathic: Jurnal Ilmiah Psikologi, 6(1), 731-742.

Hirschi, A. (2009). Career adaptability development in adolescence: Multiple predictors and effect on sense of power and life satisfaction. Journal of Vocational Behavior, 74(2), 145-155. https://doi.org/10.1016/j.jvb.2009.01.0 02

Hirschi, A. (2010). The role of chance events in the school-to-work transition: The influence of demographic, personality and career development variables. Journal of Vocational Behavior, 77(1), 39-49. https://doi.org/10.1016/j.jvb.2010.02.0 02

John, O. P., \& Srivastava, S. (1999). The Big Five trait taxonomy: History, measurement, and theoretical perspectives. In P. J. Oliver, R. Robins, \& L. . Pervins (Eds.), Handbook of personality: Theory and research (2nd Ed) (pp. 1-71). The Guilford Press.

Kemendikbud. (2017). Panduan sinkronisasi bidang keahlian di SMK dengan prioritas potensi unggulan wilayah dan tenaga kerja. Direktorat
Pembinaan Sekolah Menengah

Kejuruan Direktorat Jenderal

Pendidikan Dasar dan Menengah

Kementerian Pendidikan dan

Kebudayaan RI.

Koen, J., Klehe, U.-C., \& Van Vianen, A.

E. M. (2012). Training career adaptability to facilitate a successful school-to-work transition. Journal of Vocational Behavior, 81(3), 395-408. https://doi.org/10.1016/j.jvb.2012.10.0 03

Koen, J., Klehe, U.-C., Van Vianen, A. E. M., Zikic, J., \& Nauta, A. (2010). Jobsearch strategies and reemployment quality. Journal of Vocational Behavior, 77(1), 126-139. https://doi.org/10.1016/j.jvb.2010.02.0 04

Li, Y., Guan, Y., Wang, F., Zhou, X., Guo, K., Jiang, P., ... Fang, Z. (2015). Bigfive personality and BIS/BAS traits as predictors of career exploration: The mediation role of career adaptability. Journal of Vocational Behavior, 89, 39-45.

https://doi.org/10.1016/j.jvb.2015.04.0 06

Luthans, F. (2011). Organizational behavior. In B. Gordon (Ed.), McGraw Hill Irwin (12th ed.). https://doi.org/10.5005/jp/books/10358 23

Nauta, M. M. (2007). Career interests, selfefficacy, and personality as antecedents of career exploration. Journal of Career Assessment, 15(2), 162-180.

https://doi.org/10.1177/106907270629 8018

Nilforooshan, P., \& Salimi, S. (2016). Career adaptability as a mediator between personality and career engagement. Journal of Vocational Behavior, 94, 1-10. https://doi.org/10.1016/j.jvb.2016.02.0 10

Noordzij, G., van Hooft, E. A. J., van Mierlo, H., van Dam, A., \& Born, M. 
P. (2013). The effects of a learninggoal orientation training on selfregulation: A field experiment among unemployed job seekers. Personnel Psychology, 66(3), 723-755. https://doi.org/10.1111/peps.12011

Pulakos, E. D., Schmitt, N., Dorsey, D. W., Arad, S., Borman, W. C., \& Hedge, J. W. (2002). Predicting adaptive performance: Further tests of a model of adaptability. Human Performance, 15(4), 299-323. https://doi.org/10.1207/S15327043HU P1504_01

Ramdhani, N. (2012). Adaptasi bahasa dan budaya inventori big five. Jurnal Psikologi, 39(2), 189-207.

Reed, M. B., Bruch, M. A., \& Haase, R. F. (2004). Five-factor model of personality and career exploration. Journal of Career Assessment, 12(3), 223-238.

https://doi.org/10.1177/106907270326 1524

Rogers, M. E., Creed, P. A., \& Ian Glendon, A. (2008). The role of personality in adolescent career planning and exploration: A social cognitive perspective. Journal of Vocational Behavior, 73(1), 132-142. https://doi.org/10.1016/j.jvb.2008.02.0 02

Rossier, J., Zecca, G., Stauffer, S. D., Maggiori, C., \& Dauwalder, J.-P. (2012). career adapt-abilities scale in a french-speaking Swiss sample: Psychometric properties and relationships to personality and work engagement. Journal of Vocational Behavior, 80(3), 734-743. https://doi.org/10.1016/j.jvb.2012.01.0 04

Savickas, M. L. (1997). Career adaptability: An integrative construct for life-span, life-space theory. The Career Development Quarterly, 45(3), 247-259.

https://doi.org/10.1002/j.2161-

0045.1997.tb00469.x
Savickas, M. L. (2005). The theory and practice of career construction. In S. D. Brown \& R. W. Lent (Eds.), Career development and counseling: Putting theory and research to work (pp. 4270). John Wiley \& Sons, Inc.

Savickas, M. L., \& Porfeli, E. J. (2012). Career adapt-abilities scale: Construction, reliability, and measurement equivalence across 13 countries. Journal of Vocational Behavior, 80(3), 661-673. https://doi.org/10.1016/j.jvb.2012.01.0 11

SMKN "X" Malang.(2020, 23 Juni). (2020). Profil SMKN " $X "$ Malang. https://smknxmalang.sch.id/smknegeri-X-malang/profil/

SMKN "X" Malang. (2018a). Kuesioner siswa SMKN “ $X$ ” Malang.

SMKN "X" Malang. (2018b). Laporan Survei Kepuasan Pelanggan SMKN " $X$ ” Malang.

SMKN "X” Malang. (2019). Laporan Data Penyerapan Tamatan SMKN " $X$ " Malang.

Sugiyono. (2011). Metode penelitian kuantitatif, kualitatif dan $R$ dan $D$. Alfabeta.

Sulistiani, W., \& Handoyo, S. (2018). Career adaptability: The influence of readiness and adaptation success in the education context: a literature review. Proceedings of the $3 r d$ ASEAN Conference on Psychology, Counselling, and Humanities (ACPCH 2017), 133, 195-205. https://doi.org/10.2991/acpch17.2018 .32

Teixeira, M. A. P., Bardagi, M. P., Lassance, M. C. P., Magalhães, M. de O., \& Duarte, M. E. (2012). Career adapt-abilities scale-Brazilian form: Psychometric properties and relationships to personality. Journal of Vocational Behavior, 80(3), 680-685. https://doi.org/10.1016/j.jvb.2012.01.0 07 
Tian, Y., \& Fan, X. (2014). Adversity quotients, environmental variables and career adaptability in student nurses. Journal of Vocational Behavior, 85(3), 251-257.

https://doi.org/10.1016/j.jvb.2014.07.0 06

Tolentino, L. R., Garcia, P. R. J. M., Lu, V. N., Restubog, S. L. D., Bordia, P., \& Plewa, C. (2014). Career adaptation: The relation of adaptability to goal orientation, proactive personality, and career optimism. Journal of Vocational Behavior, 84(1), 39-48. https://doi.org/10.1016/j.jvb.2013.11.0 04

van Vianen, A. E. M., Klehe, U.-C., Koen, J., \& Dries, N. (2012). Career adaptabilities scale - Netherlands form: Psychometric properties and relationships to ability, personality, and regulatory focus. Journal of Vocational Behavior, 80(3), 716-724. https://doi.org/10.1016/j.jvb.2012.01.0 02

Wang, Z., \& Fu, Y. (2015). Social support, social comparison, and career adaptability: A moderated mediation model. Social Behavior and Personality, 43(4), 649-660. https://doi.org/10.2224/sbp.2015.43.4.6 49

Wiroko, E. P. (2017). Tantangan dan strategi rekrutmen di Indonesia. Psympathic: Jurnal Ilmiah Psikologi, 4(2), 193-204. https://doi.org/10.15575/psy.v4i2.1442

Yi, M. Y., \& Hwang, Y. (2003). Predicting the use of web-based information systems: Self-efficacy, enjoyment, learning goal orientation, and the technology acceptance model. International Journal of HumanComputer Studies, 59(4), 431-449. https://doi.org/10.1016/S10715819(03)00114-9

Yousefi, Z., Abedi, M., Baghban, I., Eatemadi, O., \& Abedi, A. (2011). Personal and situational sariables, and career concerns: Predicting career adaptability in young adults. The Spanish Journal of Psychology, 14(1), 263-271.

https://doi.org/10.5209/rev_SJOP.2011 .v14.n1.23

Zacher, H. (2014). Career adaptability predicts subjective career success above and beyond personality traits and core self-evaluations. Journal of Vocational Behavior, 84(1), 21-30. https://doi.org/10.1016/j.jvb.2013.10.0 02 